\title{
Belgeo
}

\section{The influence of ethnic policies on regional development and transport issues in Bosnia and}

Herzegovina

L'influence des politiques ethniques sur le développement régional et les problèmes de transport en Bosnie-Herzégovine

Péter Reményi, Andor Végh and Norbert Pap

(2) OpenEdition

Journals

Electronic version

URL: http://journals.openedition.org/belgeo/18991

DOI: 10.4000/belgeo.18991

ISSN: 2294-9135

Publisher:

National Committee of Geography of Belgium, Société Royale Belge de Géographie

\section{Electronic reference}

Péter Reményi, Andor Végh and Norbert Pap, «The influence of ethnic policies on regional

development and transport issues in Bosnia and Herzegovina », Belgeo [Online], 1 | 2016, Online since 16 March 2017, connection on 01 May 2019. URL : http://journals.openedition.org/belgeo/18991 DOI : 10.4000/belgeo.18991

This text was automatically generated on 1 May 2019.

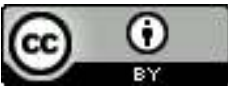

Belgeo est mis à disposition selon les termes de la licence Creative Commons Attribution 4.0 International. 


\title{
The influence of ethnic policies on regional development and transport issues in Bosnia and Herzegovina
}

\author{
L'influence des politiques ethniques sur le développement régional et les \\ problèmes de transport en Bosnie-Herzégovine
}

Péter Reményi, Andor Végh and Norbert Pap

\section{AUTHOR'S NOTE}

The present scientific contribution is dedicated to the $650^{\text {th }}$ anniversary of the foundation of the University of Pécs, Hungary.

\section{Introduction}

1 Today's Bosnia and Herzegovina (also referred to as Bosnia or $\mathrm{BiH}$ ) is an example of what happens after ethnic conflicts, separatist nationalism and unsuccessful Western-style State building. Twenty years after the Dayton Agreement - which undisputedly halted military confrontation - the most important tasks are establishing the development, operability and efficiency of the State, promoting the integration of society, as well as improving overall liveability in the country (General..., 1995; ICG, 2012; Ó Tuathail, 2006; Bildt, 2015; McMahon \& Western, 2009). The last two decades have seen several attempts (April package, Prud agreement, Butmir process) at constitutional and government reform, but efforts failed because of certain interests ${ }^{1}$ and a lack of commitment from the EU/US (Bieber, 2010).

2 True power is possessed by the ethnically organised political and economic elite of each entity who make a considerable effort to cling to their authority (ICG, 2012). In our 
opinion, this is the case with regional development in Bosnia and Herzegovina, which, before now, has only been sparsely analysed. We argue that the possession and control of territory and space is of prime importance, both during armed conflict and today, when the various participants struggle without weapons. Previously combatants tried to achieve their aims through military force and expanded their loyal population to a state of majority. Nowadays, however, it is the various instruments of regional development: education, social and return policies, transportation development, etc. (Haider, 2010, ó Tuathail \& O'Loughlin, 2009) that are utilised.

3 This paper focuses on one specific element of regional development: the development of transportation infrastructure. We argue that the entities within Bosnia and Herzegovina (the Bosnian Serb Republic/Republika Srpska - RS, and the Federation of Bosnia and Herzegovina - FBiH) each pursue policies favourable to their own entities (and thus their own ethnicity) in a documented manner in both their regional development strategies, and in reality, with the completed developments and the ones under construction. However, the characteristics of regional development (including development of infrastructure) may, for example, increase the centripetal force and territorial cohesion of a territory, thus contribute to both the economic development and the social/political stability of that region. These entity-level initiatives (as opposed to federation-level) are antagonistic, and compete for limited resources. In addition to this, in several cases, these initiatives do not serve the needs of a unified Bosnia and Herzegovina because they fail to increase the territorial cohesion as a whole (there is no federation-level forum or institution of regional development, Korjenić, 2015), which means that cohesion between the entities (at the federation level) decreases.

4 Although we understand that this is currently not the most urgent issue in Bosnia and Herzegovina, but in combination with a background of a constitutional crisis, economic stagnation, high unemployment, etc., parallel structures are slowly being established which may later on become the infrastructural basis for an increase in separatist aspirations. Obviously, these do not contribute to increasing stability in Bosnia at the moment either.

\section{Methodology}

During our research, we primarily relied on the contemporary scientific literature on this topic, the regional development documents of Bosnia and Herzegovina and its entities, as well as daily news in the media. During our on-site surveys we visited several locations mentioned in the documents ${ }^{2}$, ascertained how developments were proceeding and conducted interviews and discussions with local participants ${ }^{3}$.

6 The authors of this study earlier published papers on the geopolitical and strategic importance of transportation routes affecting the Balkans (including Bosnia and Herzegovina), in which they found that although currently the transportation in the Balkans is not of European-level importance, at the macro-regional level it plays a major role, especially for landlocked Central European States (Pap, Reményi \& Végh, 2012). One relatively new phenomenon is China's increasing interest in ports of the Eastern Mediterranean (Piraeus, Bar, Split, Rijeka, Constanta, etc.) and the corridors connecting these ports to Central and Western Europe, as part of the New Silk Road (Farkas, Pap \& Reményi, 2016). Among these, the route to Split involves transit demands affecting Bosnia. 
7 Several studies have been published on the V/C corridor linking Bosnia to major European transportation systems, including the works of Pirisi \& Reményi (2008) and Marić (2012). These also highlight the importance of developing the route following the economic axis of the country, but they also point out the obstacles and different interests of the various parties.

Reményi wrote several studies on the internal tensions of the post-war country (Reményi, 2010; 2011), highlighting that the political situation fits the definition of ethnocracy, coined by Yiftachel \& Ghanem (2004). Bieber (2010) discussed the Bosnian constitutional crisis in several studies, while the relationships of the constituting nations with each other was studied in detail by ó Tuathail \& O'Loughlin (2009), in addition to other researchers.

9 Osmanković (2001) wrote his summary work explicitly on regional development in Bosnia, in which the irrationality of post-war internal borders is highlighted from the point of view of regional development. Martina Fischer also mentions this issue, emphasising that no democratic planning policy exists in Bosnia, there is no common development forum for the different territories, instead, they are dominated by particular local interests (ESI, 2007). Aida Korjenić (Korjenić, 2015) analysed the legal and legislative framework of regional development in BiH in detail, also emphasising a lack of unified State level cooperation, the parallel practices of the various entities, as well as the consequent legislative background eroding a single national framework.

The reports of international organisations, regional and transportation regulations, development policy documents, as well as the reports in daily newspapers have all been important sources of our analysis as up to date sources of information. Our research work focused mainly on the analysis of these sources and "grey" literature (ICG, 2012; GAPUSAID, 2012).

\section{Post-Dayton Bosnia}

11 In an effort to conclude the armed conflict in $\mathrm{BiH}$, global powers and representatives from the various parties drew up the plans in Dayton for a decentralised Bosnia. In this structure, in addition to several other government functions, regional development, as well as development and control of transportation were assigned to each territorial entity. The two entities of Bosnia - that were also decentralised politically regarding their government and administration - were established along ethnic lines throughout the war, in both the geographical sense (new ethnically homogenized areas created by the conflict) and the political sense (parties based on ethnic background and their nearly continuous victory during elections; ethnically defined institutions), as well as in the social sense. Even now, the highest level of identity is ethnicity rather than nationality or citizenship.

These three factors (spatial, political, social) are strongly intertwined, since the distribution of the specific ethnicities at the end of the war was a major argument when internal borders ${ }^{4}$ were established (and thus the peace treaty indirectly legitimised ethnic cleansing), and the creation of homogeneous ethnic spaces at the subnational level was one of the objectives in Dayton. In these semi-homogeneous territorial units, political parties determined along ethnic lines and their representatives possess power, and in order to maintain their control, they have an interest in keeping ethnic tensions and 
suspicion alive, and a continuous discourse on ethnic identity versus others. Without this tension, their ethnic parties would be deemed unnecessary ${ }^{5}$. Because of the above, the ethnically organised political elites pursue development policies favourable to their own ethnically organised voters (i.e. their own ethnicity - also affecting their own ethnic territorial units because of the geographical location of the specific ethnicities).

The dominance of the ethnic principle is an inherent phenomenon of everyday life in Bosnia, and the systems operated by the elite can arguably be considered ethnocratic (Yiftachel \& Ghanem, 2004). Basically, this means that in the case of access to public goods and, in fact, most important decisions, and the operation of institutional structures, the ethnic principle becomes dominant and decisive, at both the personal and community level, as opposed to the citizenship/legal principle. This covers education, social systems, different types of benefits, the selection process of government jobs as well as development policy. In the latter case, this is primarily apparent when the "end beneficiary" of regional development is the ethnic nation (and the territory thereof) instead of the State (and its civic nation).

The characteristics of an ethnocracy, as in Bosnia, are achieved through a democratic (or nearly absolute democratic) institutional framework. In addition to this, the constitutional system of Bosnia and Herzegovina is explicitly favourable to ethnocratic solutions, since the ethnic principle is specifically included in the constitution as part of the Dayton Peace Agreement (DPA). These include the composition of the main institutions of the State reflecting the ethnic structures, the option of the ethnic veto, and in an indirect manner, the internal territorial separation based on the ethnic spatial structure, as well as the presence of ethnically organised political parties (Reményi, 2011). This is also complemented by separate regional policy and regional development for each entity (i.e. ethnicity).

Therefore in the system that is currently in operation, ethnic identity is an important factor, and the ethnically organised constitution offers territorial status to each constitutional nation, whose territory is to be protected, integrated and developed. Regional and transportation development are very important means thereof, and we argue that since these operate in an ethnic framework, it has the opposite effect to the original objectives. While regional development policy is typically a process strengthening the territorial integrity and cohesion of a State (e.g. the cohesion policy of the EU or national policies, e.g. the Lisbon Treaty), in Bosnia it contributes to the integrity of the entities, since it follows their territorial objectives. Also, because the ethnic elite apply an ethnically nationalist system of goals, regional policies also increase the centrifugal forces of Bosnia, instead of being integrative in character.

\section{The wider geopolitical context of transportation development in Bosnia}

16 In the geopolitical sense, Bosnia cannot be examined "on its own", since the ethnic determination of the late $20^{\text {th }}$ century conflict and the kin States of two (out of the three) constitutional nations in the vicinity means that the "issue of Bosnia" affects both Serbia and Croatia. This also applies to the field of transportation links, where several projects (e.g. the railway development plans of RS, the $\mathrm{E}-\mathrm{W}$ motorway construction in the RS along 
the Sava River) would be hard to comprehend without understanding the connections to the neighbouring countries.

The transport geography status of Bosnia is unique, since, in the ethnic, historical and geographical sense, it forms a very important link for its major neighbours and it has considerable practical and symbolic importance to both of them ${ }^{6}$. These relations apply in both directions, i.e. firstly regarding the (foreign) connections and strategies of $\mathrm{BiH}$, and secondly through the political activities of the aforementioned neighbouring countries affecting BiH. Historically (and nowadays as well), $\mathrm{BiH}$ was a central area of geopolitical thinking in both Croatia and Serbia.

Table 1. Major aspirations of Croatian and Serbian geopolitical thinking about BiH throughout the $19^{\text {th }}$ and $20^{\text {th }}$ centuries.

\begin{tabular}{|c|c|c|}
\hline $\begin{array}{l}\text { Geopolitical } \\
\text { scholars }\end{array}$ & Term/ideology & Interpretation of BiH as a territory \\
\hline $\begin{array}{l}\text { Garašanin, } \\
\text { Ilija - } \\
\text { politician }\end{array}$ & $\begin{array}{l}\text { Mid- } 19^{\text {th }} \text { century/Serbian } \\
\text { nationalism and geo- } \\
\text { strategy }\end{array}$ & $\begin{array}{l}\text { BiH as the primary expansion area of the } \\
19^{\text {th }} \text { century Serbia (with the core area } \\
\text { around the Dinaric Alps), the European and } \\
\text { Central European linking area, Bil is the } \\
\text { Serbian "Alsace-Lorraine" } \\
\text { (Sranjkovic, 1939; Banac, 1995). }\end{array}$ \\
\hline $\begin{array}{l}\text { Cvijić, Jovan - } \\
\text { geographer, } \\
\text { ethnographer }\end{array}$ & $\begin{array}{l}\text { Turn of the } 19^{\text {th }} \text { and } 20^{\text {th }} \\
\text { centuries, early } 20^{\text {th }} \\
\text { century/geography, } \\
\text { ethnography, cultural } \\
\text { anthropology }\end{array}$ & $\begin{array}{l}\text { Bosnia, as a diverse cultural zone, in } \\
\text { which Serbian areas (Romanija region, } \\
\text { Eastern Herzegovina) represent the "most } \\
\text { noble" patriarchal way of organising society, } \\
\text { while the "islamised" group is the oriental } \\
\text { type, considered lesser in value compared to } \\
\text { the former. The territory of Bit is not a } \\
\text { separate unit, it is a clearly Serb country, but } \\
\text { only a smaller part is the core area (Cvijici, } \\
\text { 2013). }\end{array}$ \\
\hline $\begin{array}{l}\text { Radic, Stjepan } \\
\text { - politician }\end{array}$ & $\begin{array}{l}\text { Early } 20^{\text {th }} \text { century/Croatian } \\
\text { nationalism and social } \\
\text { policy }\end{array}$ & $\begin{array}{l}\text { The unity of Bosnia may only be } \\
\text { guaranteed by (Habsburg) Austria-Hungary, } \\
\text { and legallly this is exercised through the } \\
\text { constitution and laws of Croatia (said in } \\
\text { 1908). The Croatian ethnic element is the } \\
\text { only European character represented in BiH } \\
\text { (through its existing middle class), and the } \\
\text { majority of Muslims will also join the idea of } \\
\text { Croatian and Southern Slav unity in the } \\
\text { future. The areas west of the Vrbas are } \\
\text { especially parts of the core area of the } \\
\text { Croatian State (Radic, 1908). }\end{array}$ \\
\hline $\begin{array}{l}\text { Pilar, lvo- } \\
\text { geographer, } \\
\text { historian, } \\
\text { political } \\
\text { thinker }\end{array}$ & $\begin{array}{l}\text { Interwar period /Croatian } \\
\text { geopolitics }\end{array}$ & $\begin{array}{l}\text { BiH as a core Croatian area, highlighting } \\
\text { Western European (catholic) society and } \\
\text { spatial organisation traditions in the history } \\
\text { of BiH, linking it to the Croatian areas (as } \\
\text { opposed to the Serb areas, with Byzantine } \\
\text { spatial organisation) (Pilar, 1918). }\end{array}$ \\
\hline $\begin{array}{l}\text { Vatroslav, } \\
\text { Murvar- } \\
\text { political } \\
\text { thinker, } \\
\text { historian }\end{array}$ & $\begin{array}{l}\text { Interwar and the following } \\
\text { period (during US } \\
\text { emigration)/ Croatian } \\
\text { geopolitics and economic } \\
\text { development }\end{array}$ & $\begin{array}{l}\text { The "uninterpretability" of the Croatian } \\
\text { State territory without BiH which is a } \\
\text { connection area of key importance (core } \\
\text { area) from the point of view of developing } \\
\text { the economy of the Croatian littoral } \\
\text { (primarily tourism) and linking it with the } \\
\text { national core area (Zagreb) (Murvar, 1951, } \\
1989,1999 \text { ). }\end{array}$ \\
\hline
\end{tabular}

*THIS TERM WAS COINEd BY THE SERBIAN PEOPLE'S RADICAL PARTY AND ITS LEADER, NIKOLA PAŠIĆ, BUT THEIR POLITICAL AgENDA WAS BASED ON THE IDEAS OF NAČERTANIJE (BY ILIJA GARAŠANIN), SO IN THIS CASE, REPRESENTS A POLITICAL CONTINUITY OF gOALS.

The list above shows how the territory of $\mathrm{BiH}$ is especially important for the national and territorial ideologies of Serbia and Croatia. The internal front lines pushing the boundaries from 1992 and also defining the peace agreement of 1995 developed in this spirit, with the aim of dividing the territory of the country. Since Dayton, these political aims have been officially implemented, not through devaluing the existing State framework of $\mathrm{BiH}$, but through self-administration (entity and canton) rights of Croats and Serbs, as the internal affairs of $\mathrm{BiH}^{7}$.

In addition to these, the territory of $\mathrm{BiH}$ is also important for Serbia and Croatia because they complement the transportation and communication systems of their own State territories. This is especially true for Croatia which has an enclave in Southern Dalmatia. The issues of the Neum corridor and the Pelješac bridge are very important in the 
Croatian-Bosnian relationship, as well as the question of the internal transportation corridors of BiH (partially through the Ploče port, the primary port of Bosnian goods). This is also very important regarding the traffic of Dubrovnik, one of the key tourist destinations in Croatia. Serbia is less concerned with this issue, but the accessibility of its areas and municipalities in Sandžak (the district of Priboj) and their functional (road) exclave character is important and currently ensured by the territory of the RS entity.

\section{Regional development in Bosnia and Herzegovina} Herzegovina are matters for each entity. In the Federation of Bosnia and Herzegovina, this policy and development is often decided by the authority of each canton, or, in the case of urban planning, by the municipality. This situation creates the ethnicization of what would otherwise be a professional policy. When the two halves of the country create strategies, carry out planning and development independently, the objectives of the State are marginalised. This is apparent when analysing the different regional development concepts.

However, in addition to the practice of regional development in the country merely being a contradictory mixture of regional development plans of the two entities and the Brčko District, it also represents a different regional/organisation structure. While cantonbased regional development plans have great autonomy in the territory of the FBiH (even though there is a federation-level regional development act above them), the RS has a classic centralised model (similar to the former Yugoslav system, and practically the same as the traditional Serb system). This system lacks the level of administration at the canton level, increasing the influence at the local and entity level (Korjenić, 2015). The regional development authorities of the cantons of the $\mathrm{FBiH}$ primarily provide a supplement to the majority Croat areas of the Federation to make up for the lack of their own entity, but in this case, the framework at the federation level is still the more significant and dominant regional development level (GAP-USAID, 2012). The category of areas under separate control and administration exists in practice for both entities (primarily applied to national parks). This separate administration is more important in the decentralised model of the $\mathrm{FBiH}$ and is applied when deciding areas for investment in the more (strategically) important FBiH entity, and it may primarily cause conflicts at the canton levels ${ }^{8}$.

A particular problem in the regional planning of the FBiH is a lack of funds for planning, which means that the local municipal planners cannot put together effective surveys and plans. A large number of the documents at this territorial level do not even exist, or if they do, they may be merely copies of surveys taken from the 1980s which may mean that the data is obsolete now (GAP-USAID, 2012). The more decentralised system of the FBiH also carries centralisation through financing, where the canton level dominates the Croat majority cantons, and the federation level dominates the Bosniak majority cantons, but there is no actual bottom-up work or local planning.

The latest planning document of the RS (Izmjene i dopune prostornog plana Republike Srpske do 2025. godine, 2013) is not concerned with the territory of the Federation, although it does say that in some cases, with cross border developments, the other party should be consulted. In the section which details why the development is required, the authors emphasise that the aim of planning is to reduce the territorial weaknesses and 
vulnerability of the RS, to increase the regional cohesion and competitiveness of the RS and also to strengthen the identity of the population. So, it primarily aims to support the development of the entity instead of the State, through intervention to the regional processes of the entity. This approach is suggested indirectly throughout the entire paper. The contradiction of this approach is truly perceptible in Bosnia, when, for example, small and even rural municipalities (Lukavica, Foča or Višegrad) in the Serb area are planned to develop into regional centres, next to existing centres in the vicinity but on the other side of the inter-entity boundary line (Izmjene i dopune prostornog plana Republike Srpske do 2025. godine, 2013).

In the following section, we highlight some transportation development plans and projects that we consider emblematic of the situation in $\mathrm{BiH}$, examples that support what we have stated above. Unless indicated, the newest regional development plans for each entity are used (Prostorni Plan Federacije Bosne i Hercegovine za period 2008.-2028. godine, 2012. and Izmjene i dopune prostornog plana Republike Srpske do 2025. godine, 2013).

\section{The east-west ("Posavina") axis of the Bosnian Serb Republic}

The crucial Bajna Luka-Doboj section of the main transportation route through the most densely populated and developed part of the RS is currently under construction, and some sections have already been opened to traffic. Funding for this development was in the form of an EBRD loan'. The route of the motorway connecting the capital of the entity with Serbia along the Sava river has been included in all regional development documents so far (Prostorni plan Republike Srpske 1996-2015 - Etapni plan 1996-2001, 1996; Prostorni Plan Republike Srpske do 2015. godine, 2005; Izmjene i dopune prostornog plana Republike Srpske do 2025. godine 2013), and it would also be significant at the State level, since - in addition to the V/C corridor - this is the second most important transport corridor in the country. The section which is expected to be completed in 2017 (work commenced in 2014), links Banja Luka (the capital of RS, the second largest urban area of $\mathrm{BiH}$ ) to the V/C corridor, while to the west it joins the E661 north-south route ${ }^{10}$.

However, the construction of its western (towards Prijedor, Novi Grad to Croatia) and eastern (towards Brčko, Bijeljina to Serbia) routes raises several questions. Its international importance is lessened by the fact that it practically runs parallel to an existing motorway, 30 to $50 \mathrm{~km}$ to the south. The once symbolic "Brotherhood and Unity Highway" running on the other side of the Sava (in the territory of another country) connects Zagreb with Belgrade, just as the international relation of the "Posavina" motorway would. This is one of the reasons why this motorway is not included in the European "E" road network.

Further south runs another route, serving connections considered more important in the Yugoslav era, along the Banja Luka-Doboj-Tuzla-Bijeljina/Zvornik route to Serbia. This route crosses the inter-entity boundary several times (figure 1.) Even so, passenger traffic between Doboj and Tuzla is three times more than from Doboj in the direction of the proposed motorway (more than 9000 vehicles per day compared to more than 3000 per day) (Framework transport strategy of Bosnia and Herzegovina - Draft, 2016). In addition, Bosniak politicians would like to see yet another E-W corridor constructed further to the 
south (Serbian border-Goražde-Sarajevo-Jajce-Banja Luka-Croatian border), which would partly be an improvement of the international road E661 ${ }^{11}$.

The domestic importance is primarily reduced by the route running almost entirely within the area of the RS (with an interception in Brčko), even though, to do that, it has to avoid some major urban centres. These include Tuzla (the route passes north of it) and Bihać where it could logically continue, but instead, the route crosses the border in the territory of the RS toward Croatia. The V/C should be preferred to the "Posavina" motorway in every domestic and international sense, however it is the latter which is being currently constructed, which is a prime example of the inefficient use of limited resources of the State budget. The Motorway Management Corporation of the RS (Autoputevi Republike Srpske) states on its website that this motorway is the cornerstone of the territorial integrity of the RS (and not of $\mathrm{BiH})^{12}$. Also significant is that while the Banja Luka-Doboj section is financed by European institutions the two "flanks" seem to be constructed by Chinese companies and financed either under PPP conditions or by Chinese financial institutions (China Shadong International Economic \& Technical Cooperation Group Ltd. and China Road and Bridge Corporation) $)^{13}$. Although, it has only symbolic significance, the motorway is named " $9^{\text {th }}$ January", which is the national holiday of the RS. This holiday has been ruled unconstitutional by the Constitutional Court of $\mathrm{BiH}$ ${ }^{14}$.

Figure 1. The "Posavina” corridor.

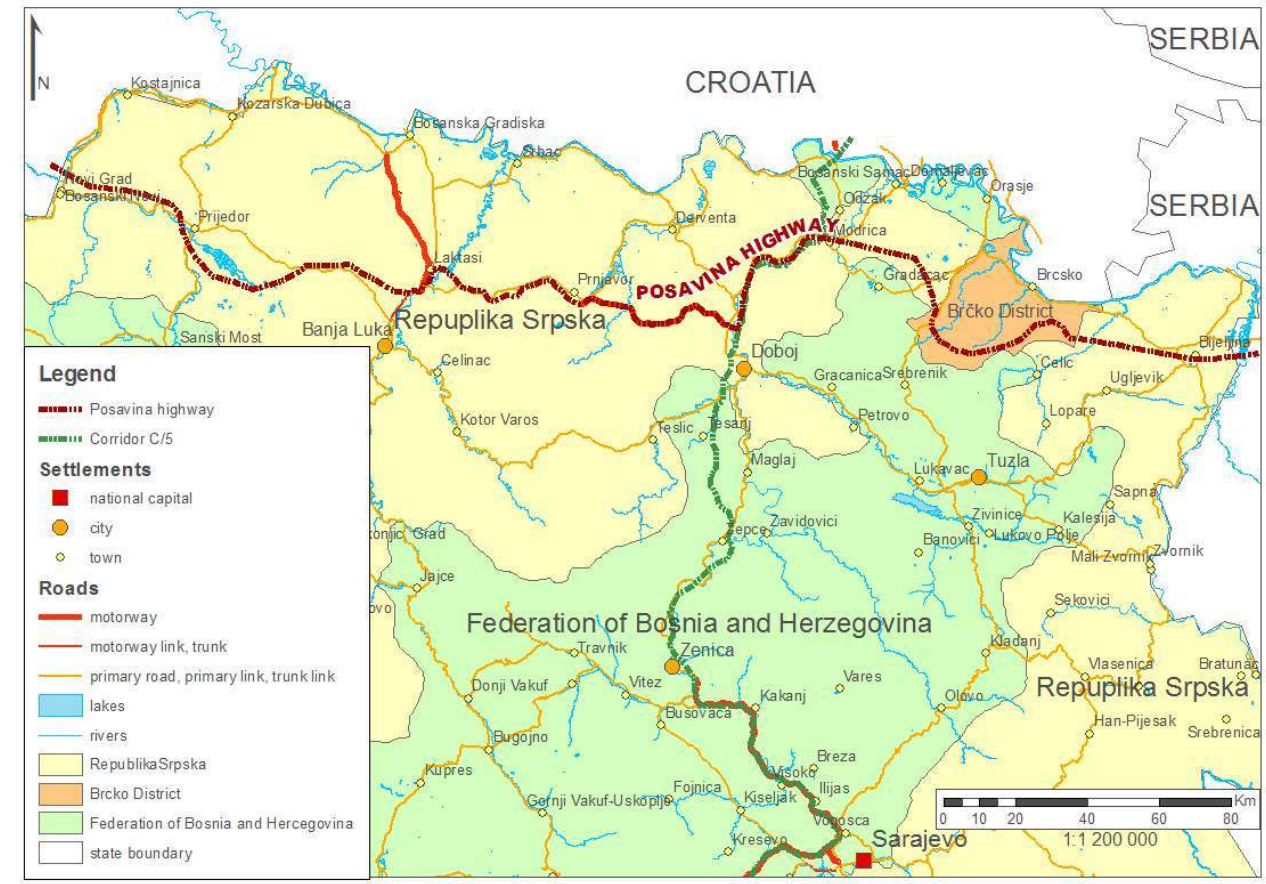

SOURCE: PROSTORNI PLAN REPUBLIKE SRPSKE DO 2015. gODINE; CARTOgRAPHY: SIMON B.

\section{Bosnian "exit" to Croatia through Tuzla}

The most important transportation, social, economic, innovation vein of Bosnia and Herzegovina is the V/C corridor in the north-south direction $(50 \%$ of the State's population and $60 \%$ of the GDP produced are within the $30 \mathrm{~km}$ range of the corridor - 
Marić, 2012), and it is also the only element of the TEN network affecting Bosnia. The related motorway route enters the territory of the RS from the FBiH at Doboj, and after approximately $50 \mathrm{~km}$ it returns to the $\mathrm{FBiH}$ to reach Croatia. It serves more than 7000 vehicles daily - and at urban agglomerations this may more than double (Framework transport strategy of Bosnia and Herzegovina - Draft, 2016).

Generally, the elite of the $\mathrm{FBiH}$, and thus regional planners also prefer pan-Bosnian solutions. The main reason is that long-term demographic trends ${ }^{15}$ favour them, which after a future constitutional reform - would solidify the power of the Bosniak elite in the entire country, giving way to disassembling ethno-territorial structures along Bosniak interests. However, a route parallel to the V/C corridor (the most pan-national of all transportation routes) was also planned, which would split at Žepce, linking the southern section of the V/C with Croatia but remaining completely in the territory of the FBiH (except for Brčko) (figure 2.). In addition to this route directly linking Tuzla with the corridor, it would also avoid the $50 \mathrm{~km}$ Serb section as well. The alternative motorway running only a few kilometres away from the original route (but on the other side of the inter-entity boundary) has mostly political significance.

Figure 2. The "Tuzla exit".

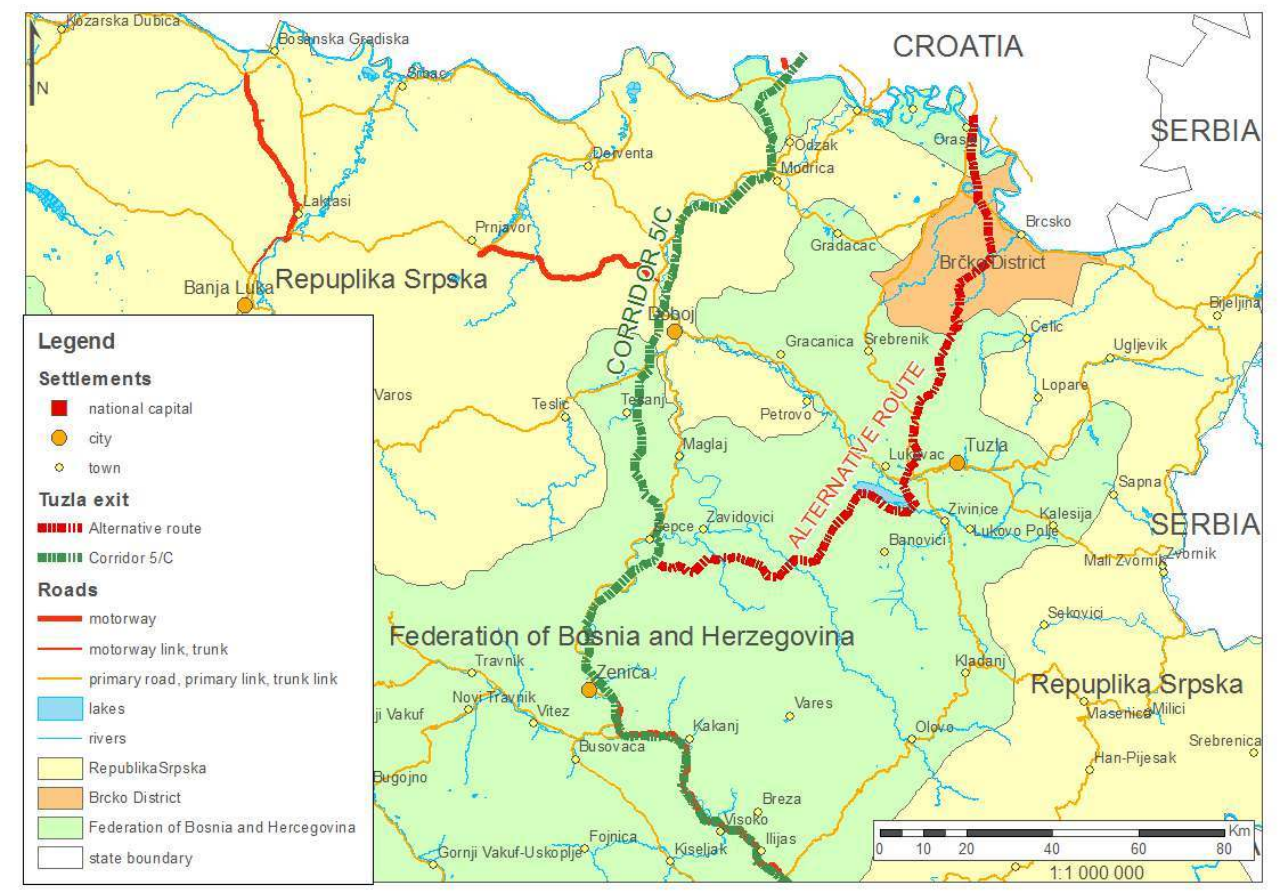

SOURCE: PROSTORNI PLAN FEDERACIJE BOSNE I HERCEgOVINE...; CARTOgRAPHY: SIMON B.

\section{The Eastern-Herzegovina route}

Eastern-Herzegovina also has competing infrastructure development plans. The dissolution of Yugoslavia left the region in a unique State, because its actual centre, Dubrovnik went on to become part of the independent Croatia (with a narrow seashore), and the urban township of the catchment area, Trebinje belongs to the RS. But a strip lacking real towns is caught between the Croatian-Bosnian border and the IEBL, which is 
part of the FBiH. A highway connecting the area to the north with Mostar and the V/C corridor, and to the south with Trebinje and Montenegro would be important for the development of the Herzegovina areas belonging to the RS and to the FBiH. These plans are presented in the documents of both entities, but "naturally" with entirely different routes. In the plans of the $\mathrm{FBiH}$ the highway runs on the Bosnian-Croatian side of the IEBL, while in the Serb plans it runs on the Serb side of the border, a few kilometres to the east (figures 3-4).

Figure 3. Eastern Herzegovina RS version.

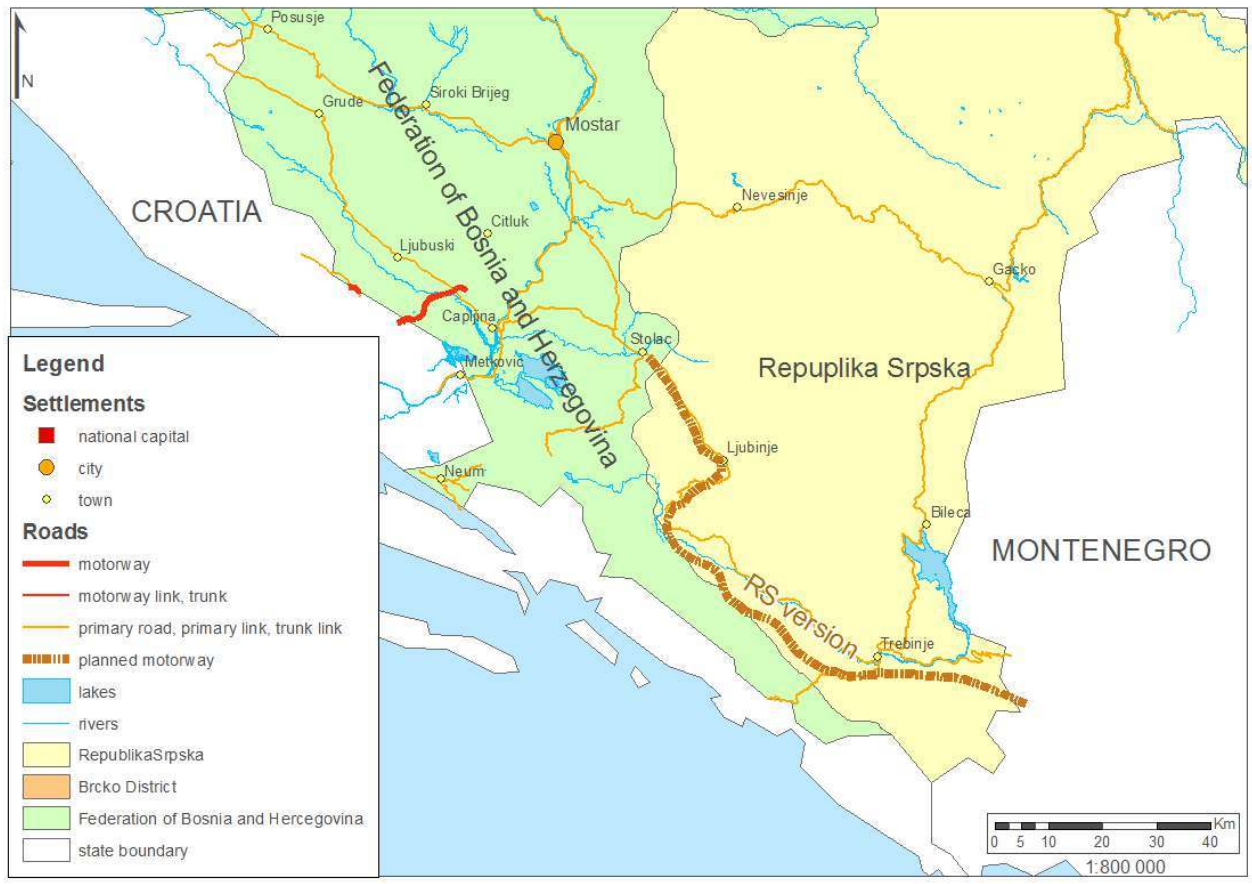

SOURCE: PROSTORNI PLAN REPUBLIKE SRPSKE DO 2015. gODINE; CARTOgRAPHY: SIMON B.

The latter route may be more "viable" considering it was included in the plans for the modernisation of existing roads, which serve more than 1000 vehicles daily (Framework transport strategy of Bosnia and Herzegovina - Draft, 2016), at the edge of the Popovo polje, with relatively favourable inclinations. However, the highway included in the plans of the FBiH would be an entirely new, "green field" investment, in a mountainous area. The latter would link hardly accessible rural areas and new centres (Ravno, with a population of approximately 3000) to modern transportation networks, and would only reach the territory of the RS after connecting to the Trebinje-Dubrovnik road. Contrary to this, the version of the RS would entirely avoid the land strip of the FBiH stuck between Dubrovnik and Trebinje, and only enter the territory of the FBiH at the municipality of Stolac, connecting the neighbouring Ljubinje (instead of Ravno) to the network. The Croat majority in Southeast Herzegovina are also looking for alternative connections towards Croatia, strengthening links with their kin State ${ }^{16}$. 
Figure 4. Eastern Herzegovina FBiH version.

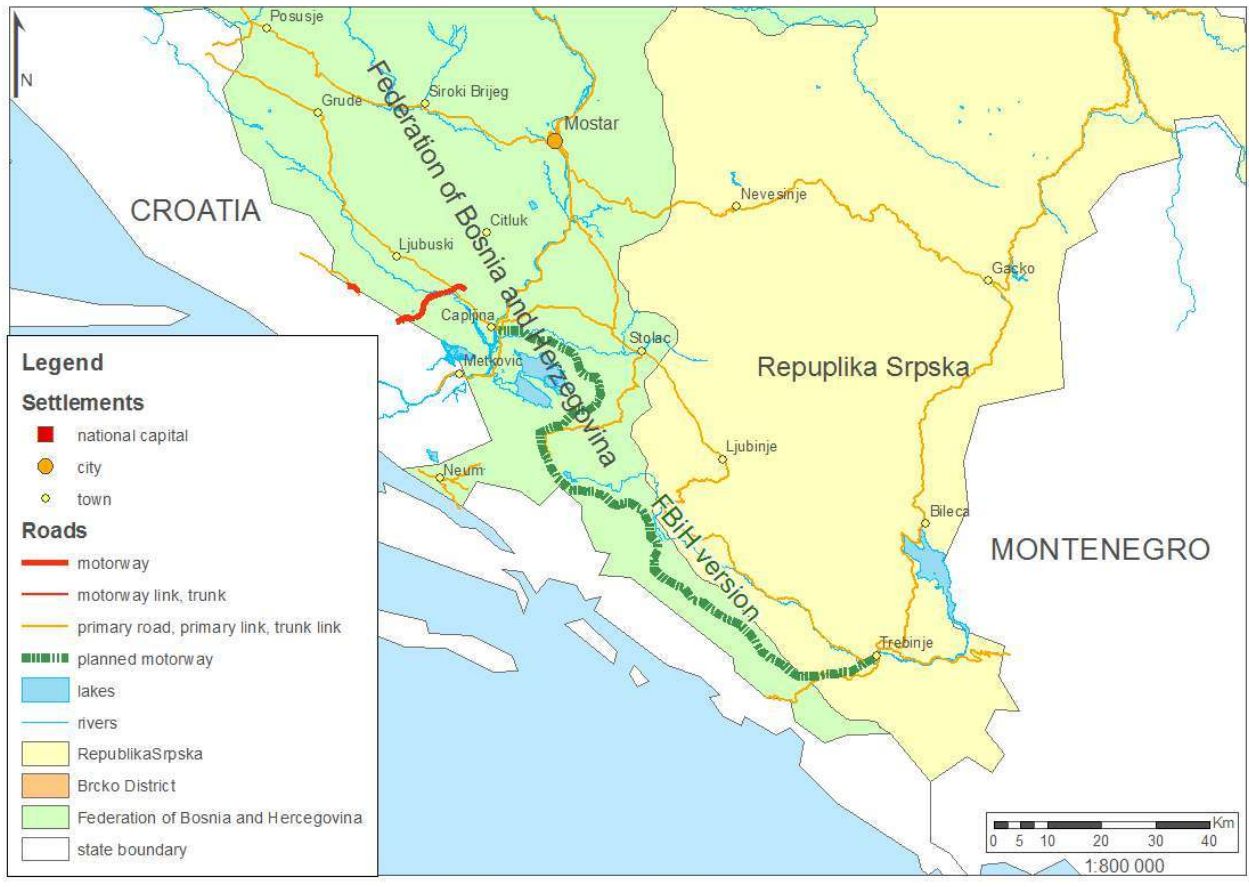

SOURCE: PROSTORNI PLAN FEDERACIJE BOSNE I HERCEgOVINE...; CARTOgRAPHY: SIMON B.

\section{Railway development plans of the Bosnian Serb Republic}

The transportation development plans that are the greatest in scale, but probably the least likely to be completed, affect railway infrastructure. All regional development documents of the RS include extensive railway development plans, and many of these affect regions where topographic conditions are absolutely unfavourable to railway transport, and where construction would require a huge budget. In addition, those areas affected often have a very low population density, so the utilisation of the future infrastructure is also questionable. We can only rely on road traffic volumes when estimating the volume of traffic for the proposed railroad, and this is the part of the road network of BiH with the least traffic. In some sections (e.g. between Foča and Gacko) it is well below 1000 vehicles/day (Framework transport strategy of Bosnia and Herzegovina Draft, 2016).

The rugged nature of the topography would also require the construction of several infrastructural elements (tunnels, bridges, etc.) for the railway running along the left bank of the Drina. This line would connect to the Serbian railways at Zvornik and Višegrad, and would run to the south to Trebinje in the territory of the RS, where it would split toward the V/C corridor and Montenegro.

Considering the connections, the hardship of construction and the related costs, the planned line would be the repetition of the Belgrade-Bar railway slightly to the west. At the time of its construction it was already one of the most expensive railways in the world, and also has very low utilisation rates (but similarly, it is a venture of great 
symbolic and (geo)political importance). It would also run parallel to the railway of the $\mathrm{V} / \mathrm{C}$ corridor, but while the latter would connect the urban and high-population density, economically active areas (in the Bosnian sense) with international networks, the planned line would connect scarcely populated areas with a depressed economy to the Serbian network.

Figure 5. The railway development plans of the RS.

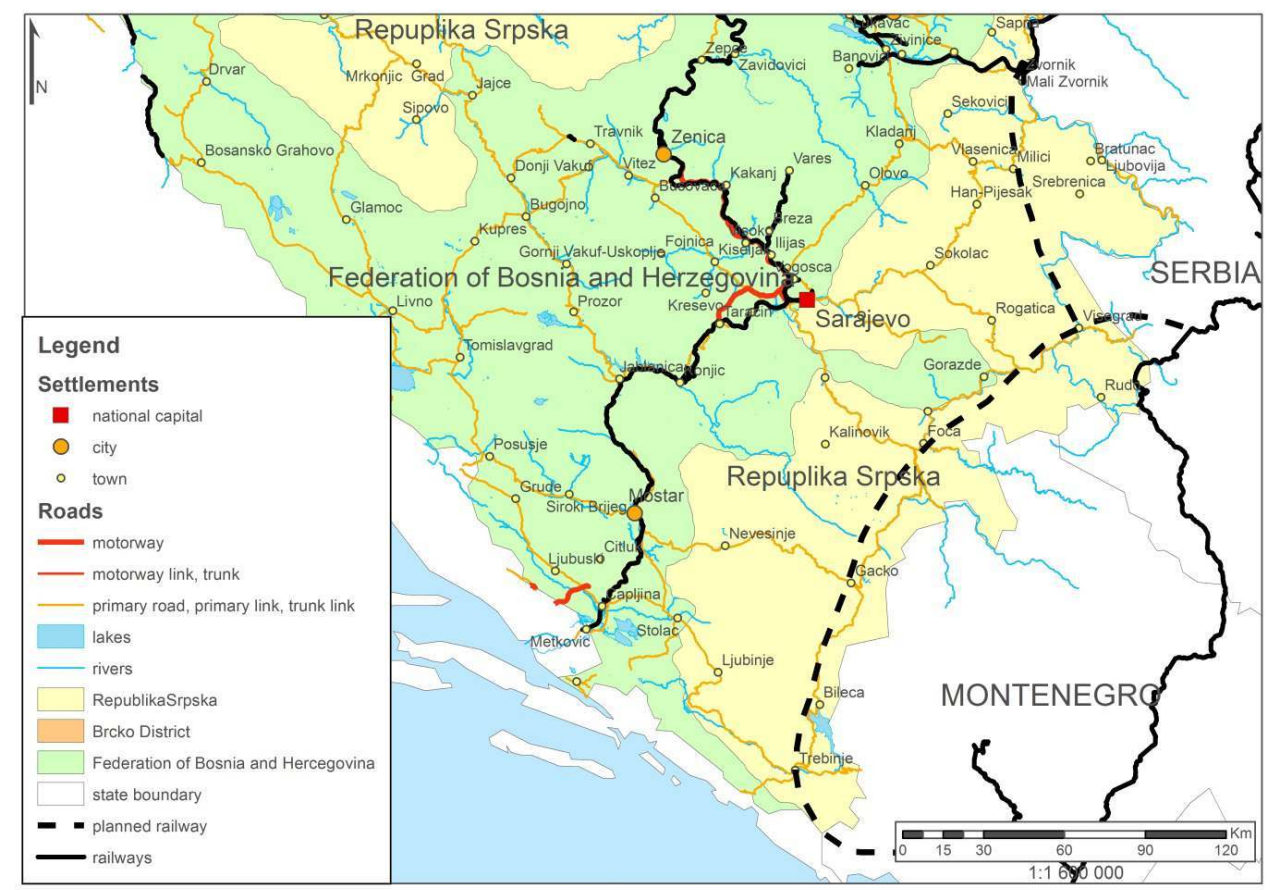

SOURCE: PROSTORNI PLAN REPUBLIKE SRPSKE DO 2015. gODINE; CARTOgRAPHY: SIMON B.

\section{Banja Luka-Split motorway}

The Banja Luka-Split motorway, which already has feasibility plans, a future financier and contractor (Sinohydro), is somewhat similar to the railway development plans ${ }^{17}$. This motorway would also be constructed between two existing or high-priority projects (even though the existing roads lack significant traffic - Framework transport strategy of Bosnia and Herzegovina - Draft, 2016), running parallel to them and serving an almost identical role, but would primarily align with Bosnian Serb and Croat interests. The planned motorway would run between the Croatian Adriatic motorway (Zagreb-Split) and the V/C corridor, and it would link Banja Luka, Posavina and also Central Europe to the Adriatic Sea at Croatia's second most important city, the tourist centre of Split, through the majority Croat region of Herzegovina. This would serve the interests of both the Bosnian Serb Republic (because it would be an important north-south link within the entity) and the majority Croat Herzegovina (as it would link the city of Split to the majority Croat hinterland in Herzegovina). This route would also be useful for linking Central Europe transit tourists and the Croatian seaside (the plan already existed in the Yugoslav era), since it would simplify and speed up travel to the Croatian coast. The only stakeholder who considers the route less important would be the Bosniak community, 
because the route avoids their current majority area, and directs transit traffic (and the associated income), to the RS and the Croat cantons.

It should also be noted that according to the local press ${ }^{18}$, both motorway management corporations of the RS and the FBiH consider the project, which is financed by Chinese companies, to be important.

\section{Conclusion}

Since transportation systems and their development are fundamentally important for a region to develop economically, and thus to ensure integrity, cohesion and liveability, it is no surprise that in a State and society as divided along ethnic lines as Bosnia is, problems related to this issue have ethnic connotations. In any part of the world, most local communities desire significant infrastructural systems be developed along their own interests (even in Hungary, where local lobbying plays an important part in motorway and railway development). In Bosnia, however, the struggle by local actors for economic benefits and power, is immediately transformed into a competition along ethnic lines as well. The Dayton system provides a framework for this issue, providing territorial separation and an array of related powers (including regional development) to each ethnic community, who also exercise these powers. The integration and operation of the entities specified in Dayton requires sufficient infrastructure for each of these units.

If we put the transportation development plans on an estimated ethnic map, the ethnoterritorial determination of development policy becomes clear. The Serb development projects we highlighted (due to different reasons - demography, separatist efforts unique solutions are more apparent in the case of the RS) affect practically all majority Serb municipalities, and when because of spatial rationale they would reach the territory of another entity, they tend to "curve". Likewise, the plans of the Federation also operate similarly - it is not difficult to see the objective of running in one's own territory. 
Figure 6. Transportation development and ethnic majorities.

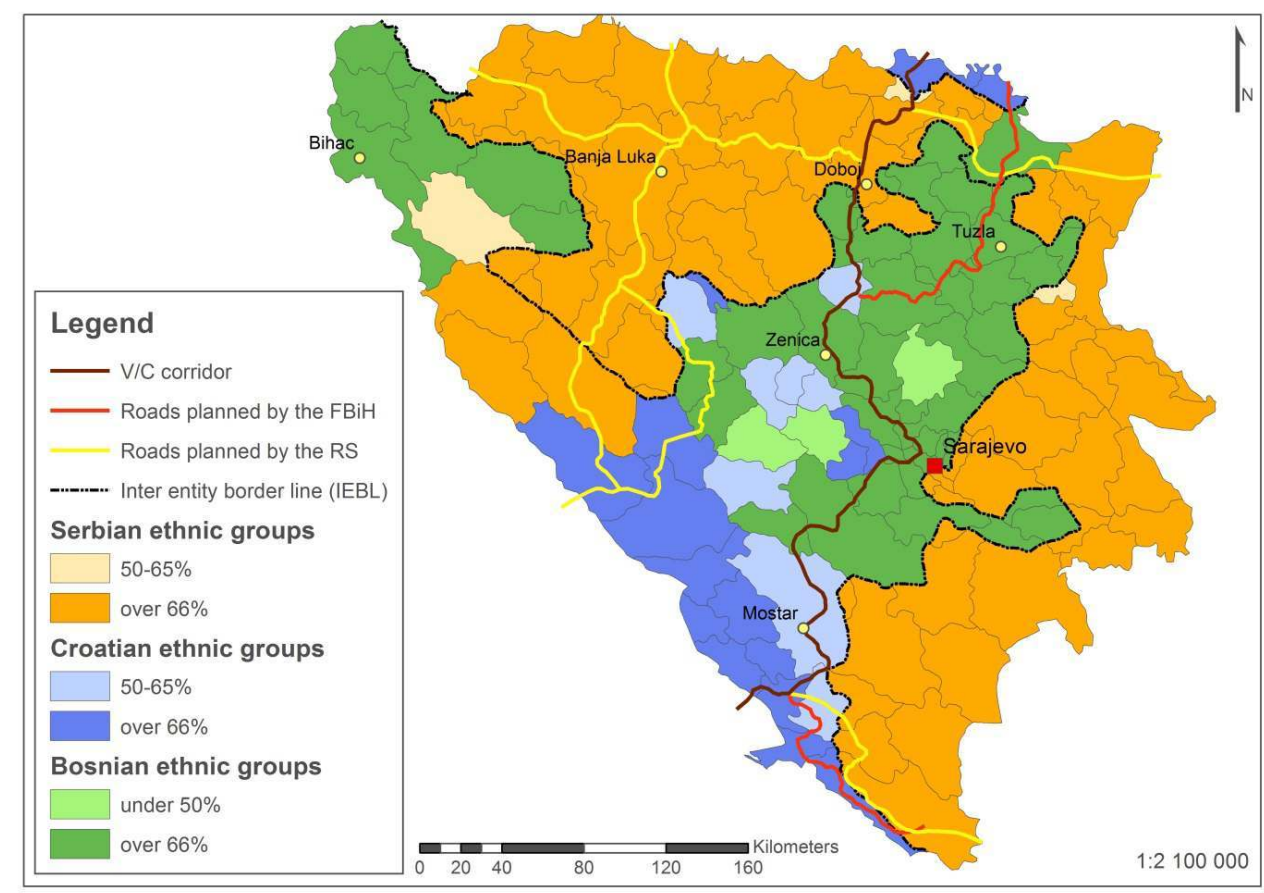

Cartography: Simon B. transportation development) in Bosnia is implemented according to an ethno-territorial logic. In a small country lacking resources, which is also hindered by internal separatist tensions, transportation development implemented along the lines of ethnic thinking results in the establishment of parallel structures and a waste of resources. The underlying issue is due to the conflict of the ethno-nationalist elites, but the institutions which enable this were created by Dayton. It would be desirable to change this, and a State-level integrated regional policy would be an important pillar of a stable Bosnia and Herzegovina, but based on the failures of the previous attempts, we have no illusions that this will occur in the near future. 


\section{BIBLIOGRAPHY}

ARNAUTOVIĆ S., MUJAGIĆ N., KAPIDŽIĆ D., OSMIĆ A. \& HURUZ E. (2015), Political Pluralism and Internal Party Democracy: Bosnia and Herzegovina, Podgorica, CeMI.

BANAC I. (1995), Nacionalno pitanje u Jugoslaviji, Zagreb, Durieux.

BIEBER F. (2010), “Constitutional reform in Bosnia and Herzegovina: preparing for EU accession”, European Policy Centre, www.epc.eu.

BILDT C. (2015), “Dayton revisited: Bosnia's peace deal 20 years on”, European Council on Foreign Relations, ECFR/149, November 2015, ecfr.eu.

CVIJIĆ J. (2013), Balkansko poluostrvo i južnoslovenske zemlje: Osnove antropogeografije, Beograd, Narodna Biblioteka Srbije.

EUROPEAN STABILITY INITIATIVE (ESI) (2007), “The need for economic development and Democratic planning”, in FISCHER M. (ed.), Peacebuilding and civil society in Bosnia-Herzegovina, LIT Verlag, Berlin, pp. 69-106.

FARKAS Z.A., PAP N. \& REMÉNYI P. (2016), “Hungary's place on Eurasian rail land bridges and the eastern opening", Hungarian Geographical Bulletin 65, 1 pp. 3-14.

Framework transport strategy of Bosnia and Herzegovina - Draft (2016), http://www.mkt.gov.ba/ aktivnosti/default.aspx?id=5026\&langTag=bs-BA (last accessed: 02.03.2016).

GAP - Governance acountability project - USAID (2012), Politika u oblasti prostornog planiranja, http://www.sogfbih.ba/uploaded/DOKUMENTI/Urbanizam/Politika\%20u\%20oblasti\% 20prostornog\%20planiranja.pdf (accessed: 30.08.2015).

HAIDER H. (2010), “The Politicisation of Humanitarian Assistance: Refugee and IDP Policy in Bosnia and Herzegovina", The Journal of Humanitarian Assistance, https://sites.tufts.edu/jha/ archives/700 (accessed: 06.09.2015).

HAYDEN R. M. (2012), From Yugoslavia to the Western Balkans: Studies of a European DisunioN 1991-2011 , BostoN Brill.

ICG (2012), "Bosnia's Gordian Knot: Constitutional Reform”, Europe Briefing, 68, Sarajevo-IstanbulBrussels, www.crisisgroup.org.

Izmjene i dopune prostornog plana Republike Srpske do 2025. godine (2013), Banja Luka, 342 p.

KORJENIĆ A. (2015), “Prostorno planiranje u Bosni i Hercegovini - Legislativni okvir”, Acta Geographica Bosniae et Hercegovinae, 3, pp. 63-74.

MARIĆ D. (2012), “Corridor V/C as a factor of integration of Bosnia and Herzegovina into the European Union", Journal of the Geographical Institute "Jovan Cvijić" Sasa, 62, 1, pp. 89-101.

MCMAHON P.C., WESTERN J. (2009), "The Death of Dayton. How to stop Bosnia from falling apart", Foreign Affairs, 88, 5, pp. 69-83.

MURVAR V. (1951), “Hrvatsko obilježje Bosne i Hercegovine u tursko doba”, Hrvatska Revija, 2, pp. 131-138. 
MURVAR V. (1989), Nation and religion in Central Europe and the Western Balkans: the Muslims in Bosna, Hercegovina and Sandžak: A sociological analysis, Brookfield, FSSSN Colloquia and Symposia.

MURVAR V. (1999), Na tragovima srpskih neistina (reprint), Zagreb, Croatiaprojek.

OSMANKOVIĆ J. (2001), “Regional development of Bosnia-Herzegovina”, in European Regional Development Issues in the New Millennium and their Impact on Economic Policy, $41^{\text {th }}$ Congress of the European Regional Science Association, Zagreb, 19 p.

Ó TUATHAIL G. (2006), "Geopolitical Discourses: Paddy Ashdown and the Tenth Anniversary of the Dayton Peace Accords", Geopolitics, 11, pp. 141-158.

Ó TUATHAIL G., O’LOUGHLIN J. (2009), “After Ethnic Cleansing: The Returns Process in BosniaHerzegovina a Decade beyond War", Annals of the Association of American Geographers, 99, 5, pp. 1045-1053.

PAP N., REMÉNYI P. \& VÉGH A. (2012), “Corridors in the Western Balkans and the Hungarian exit to the sea", Revista Romana de Geografie Politica, 14, 2, pp. 176-188.

PAP N., REMÉNYI P. \& VÉGH A. (2010), “Új állam a Balkánon: A Republika Srpska” [“New State in the Balkans: The Republika Srpska"], Földrajzi Közlemények [Hungarian Geographical Review], 134, 3, pp. 313-327.

PILAR I. (pseudo.), SÜDLAND L.V. (1918), Die südslawische Frage und der Weltkrieg. Uebersichtliche Darstellung des Gesamt - Problems.

PIRISI G., REMÉNYI P. (2008), “Corridor V/C - Infrastructural development = regional development? A possible Hungarian perception”, in NURKOVIC R. (ed.), Utjecaj prometa na reigonalni razvoj: Traffic influence of the regional development, Univerza na Primorskem, Koper, pp. 69-74.

Prostorni Plan Federacije Bosne i Hercegovine za period 2008.-2028. godine (2012), Sarajevo-Mostar, 294 p.

Prostorni plan Republike Srpske 1996-2015 - Etapni plan 1996-2001 (1996), Banja Luka, Urbanistički zavod Republike Srpske.

Prostorni Plan Republike Srpske do 2015. godine (2005), Banja Luka 405 p.

RADIĆ S. (1908, 1993), Živo hrvatsko pravo na Bosnu i Hercegovinu (reprint), Zagreb, Consilium.

REMÉNYI P. (2010), "Some aspects of demographic consequences of the breakup of former Yugoslavia”, in TARRÓSY I., MILFORD S. (eds.), The Western Balkans: Lessons from the Past and Future Prospects - A View from the Danube Region Pécs, Publikon Kiadó, pp. 41-54.

REMÉNYI P. (2011), “An Emerging Border of an Emerging State? The Case of the IEBL and the Republika Srpska of Bosnia-Herzegovina”, Eurolimes, 11, pp. 129-141.

REMÉNYI P. (2012), “The statehood of Bosnia-Herzegovina according to the Hartshorne model”, Historia Actual Online, 27, pp. 129-140.

SRANJKOVIĆ D. (1939), “Kako je postalo Garašaninovo “Načertanije”, Spomenik SKA, XCI, Beograd, pp. 76-102.

UNITED NATIONS (1995), General framework agreement for peace in Bosnia and Herzegovina, http://peacemaker.un.org/sites/peacemaker.un.org/files/BA_951121_DaytonAgreement.pdf YIFTACHEL O., GHANEM A. (2004), “Understanding 'ethnocratic' regimes: the politics of seizing contested territories”, Political Geography, 23, pp. 647-676. 


\section{Newspaper articles}

"Autoput Banja Luka - Doboj bit će gotov 2017. godine, prvih $36 \mathrm{~km}$ u prometu ovog ljeta" (2016), Klix.ba, 06.08.2016, https://www.klix.ba/vijesti/bih/autoput-banja-luka-doboj-bit-ce-gotov-2017godine-prvih-36-km-u-prometu-ovog-ljeta/160802038 (accessed: 03.02.2017).

"Autoput Banja Luka - Doboj nosit će naziv '9. januar'" (2016), Depo PortaL 31.08.2016, http:// depo.ba/clanak/151559/autoput-banja-luka-doboj-nosit-ce-naziv-9-januar (accessed: 03.02.2017).

"Autoput Banja Luka-Split je u interesu RS-a i FBiH" (2014), Dnevni Avaz 29.10.2014, http:// www.avaz.ba/clanak/143295/autoput-banja-luka-split-je-u-interesu-rs-a-i-fbih? url=clanak/143295/autoput-banja-luka-split-je-u-interesu-rs-a-i-fbih\#sthash.o3sp9GPk.dpuf (accessed: 09.09.2016).

"Autoput: RS bi jednom, a Sarajevo drugom trasom do Beograda" (2017), Hercegovina.info, 25.01.2017, https://www.hercegovina.info/vijesti/vijesti/bih/autoput-rs-bi-jednom-a-sarajevodrugom-trasom-do-beograda-120037 (accessed: 03.02.2017).

"Kinezi izradili studiju za autoput Banjaluka - Mliništa" (2015), Nezavisne Novine 04.11.2015 http://www.nezavisne.com/ekonomija/privreda/Kinezi-izradili-studiju-za-autoput-BanjalukaMlinista/334391 (accessed: 09.09.2016).

"Mostar se cestom preko Širokog i Gruda povezuje sa hrvatskom autocestom," (2016), Večernji List, 05.01.2016. http://www.vecernji.ba/mostar-se-cestom-preko-sirokog-i-gruda-povezuje-sahrvatskom-autocestom-1049845 (accessed: 03.02.2017).

"Otvoren auto-put "9. Januar": Dodik i Vučić presekli vrpcu" (2016), Telegraf.rs, 11.09.2016. http://www.telegraf.rs/vesti/2351156-otvoren-auto-put-9-januar-dodik-i-vucic-presekli-vrpcu (accessed: 03.02.2017.)

"Zašto kasni izgradnja autocesta u BiH, Aljazeera Balkans" (2017), http://balkans.aljazeera.net/ vijesti/zasto-kasni-izgradnja-autocesta-u-bih (accessed: 03.02.2017).

\section{NOTES}

1. E.g.: Serb and Croat politicians disagree with the unified presidency, which would favour the largest constituent nation, the Bosniaks (April package). Serb politicians refuse the division of second level territorial administration into four (instead of the current two), since it would mean the dissolution of the RS (Prud agreement). For further information see: Hayden, 2012.

2. Study trips were organized in July 2016 to Banja Luka, Doboj, Sarajevo, Trebinje, Foča, visiting the construction sites (around Doboj), the existing infrastructure (V/C corridor, Banja Luka) and the planned routes (around Trebinje, around Foča and around Mrkonjić Grad).

3. Discussion with local participants included H.E. József Négyesi, ambassador of Hungary to Bosnia and Herzegovina (September 2015, July 2016, December 2016), H. E. Valentin Inzko, High Representative for Bosnia and Herzegovina (September 2015), Ešref Kenan Rašidagić, assistant Professor, Faculty of Political Science University of Sarajevo (July 2016), Nusret Drešković and Ranko Mirić, assistant professors Faculty of Natural Sciences and Mathematics University of Sarajevo (March 2015), Haris Mešinović, independent researcher, Sarajevo (May 2015).

4. The Inter-entity Boundary Line (IEBL), separating the two self-governing entities (FBiH and RS) of $\mathrm{BiH}$ and the cantonal borders.

5. The party structure in BiH is fundamentally ethnic-based instead of ideology. Multi-ethnic parties experienced a short flourish after the war, but following two parliamentary cycles parties with nationalist programmes remained dominant. Currently the Democratic Front and the Social 
Democratic Party are the strongest multi-ethnic parties. The leading party of the Bosniaks is the Party of Democratic Action (SDA) which also had political leadership during the war. The majority of the ethnic Croats vote for HDZ BiH which is like a subsidiary of the HDZ conservative party in Croatia. HDZ BiH also existed during the war running a Croat nationalist agenda. The major party of the Bosnian Serbs is the Independent Social Democratic Party (SNSD), which, in contrast to its name, promotes Serb nationalist and secessionist views. The Serb Democratic Party (SDS), the major opposition party in the RS, being the wartime party of Bosnian Serbs is also organized on ethnic grounds. For further information on the political and party systems of BiH see: Arnautović et al., 2015.

6. This importance derives from historical, geopolitical, cultural, mythical as well as ethnopolitical considerations. The kin states of both the Bosnian Croats and Bosnian Serbs and their political elite perceive Bosnia as a unit where they have special interests. This can be traced throughout their history, but here we show only some major modern scholars and their views.

7. Even now, in each instance of an internal crisis developing within $\mathrm{BiH}$ (constitutional, administrative, social, etc.), the instant reactions, expressed opinions and semi-official visits of Serbian and Croatian political leaders, as well as the relationships of their internal Croat and Serb counterparts in $\mathrm{BiH}$, which make the internal and foreign borders seem invisible or reevaluate them, are also apparent.

8. Funding of the preparation of local development plans are unregulated and unsolved in the FBiH. This is acknowledged in legislation where it is stated that until the new regional development plans are ready, local development plans from 1981 to 2000 are used as long as they do not conflict with the constitution. http://www.fmpu.gov.ba/prostorni-plan-fbih - last accessed: 03.02.2017.

9. "Otvoren auto-put '9. Januar': Dodik i Vučić presekli vrpcu" (2016).

10. "Autoput Banja Luka - Doboj bit će gotov 2017. godine, prvih $36 \mathrm{~km}$ u prometu ovog ljeta" (2016).

11. "Autoput: RS bi jednom, a Sarajevo drugom trasom do Beograda" (2017) and "Zašto kasni izgradnja autocesta u BiH, Aljazeera Balkans" (2017).

12. http://www.autoputevirs.com/aprs/Doc.aspx?cat $=2 \&$ subcat $=59 \&$ lang $=$ eng\&id $=81 \& b r=0$ (last accessed: 02.02.2017).

13. "Autoput Banja Luka - Doboj bit će gotov 2017. godine, prvih $36 \mathrm{~km}$ u prometu ovog ljeta" (2016).

14. "Autoput Banja Luka - Doboj nosit će naziv '9. januar'" (2016).

15. Differences in demographic trends are visible between the RS and the FBiH. Natural decrease is characteristic for all municipalities in RS but Banja Luka and Zvornik in the first decade of the $21^{\text {st }}$ century. These trends are also present in the Croat majority municipalities of Western Herzegovina. On the other hand the natural changes are positive in the Bosniak majority municipalities of the FBiH (see more in Pap, Reményi \& Végh, 2010) the raw data is retrieved from: Federalni zavod za statistiku (2010), Unsko-sanski kanton u brojkama (2011), Federalni zavod za statistiku, pg.10, http://fzs.ba/Podaci/01.pdf; Federalni zavod za statistiku (2010), Posavski kanton $\mathrm{u}$ brojkama (2011), Federalni zavod za statistiku, pg.7, http://fzs.ba/ Podaci/02.pdf; Federalni zavod za statistiku (2010), Tuzlanski kanton u brojkama (2011), Federalni zavod za statistiku, pg.11, http://fzs.ba/Podaci/03.pdf; Federalni zavod za statistiku (2010), Zeničko-dobojski kanton u brojkama (2011), Federalni zavod za statistiku, pg.10, http:// fzs.ba/Podaci/04.pdf; Federalni zavod za statistiku (2010), Bosansko-podrinjski kanton u brojkama (2011), Federalni zavod za statistiku, pg.7, http://fzs.ba/Podaci/05.pdf; Federalni zavod za statistiku (2010), Srednjobosanski kanton u brojkama (2011), Federalni zavod za statistiku, pg.Metodološka objašnjenja nisu dostupna., http://fzs.ba/Podaci/06.pdf; Federalni zavod za statistiku (2010), Hercegovačko-neretvanski kanton u brojkama (2011), Federalni zavod za statistiku, pg.10, http://fzs.ba/Podaci/07.pdf; Federalni zavod za statistiku (2010), Zapadno- 
hercegovački kanton u brojkama (2011), Federalni zavod za statistiku, pg.10, http://fzs.ba/ Podaci/08.pdf; Federalni zavod za statistiku (2010), Kanton Sarajevo u brojkama (2011), Federalni zavod za statistiku, pg.11,http://fzs.ba/Podaci/09.pdf; Federalni zavod za statistiku (2010), Kanton 10 u brojkama (2011), Federalni zavod za statistiku, pg.10, http://fzs.ba/Podaci/10.pdf, all website accessed on: 2011.10.26 and Republički zavod za statistiku Republike Srpske (2010), Procjena broja stanovnika Republike Srpske po opštinama za 2010. godinu, Republički zavod za statistiku Republike Srpske.

16. "Mostar se cestom preko Širokog i Gruda povezuje sa hrvatskom autocestom" (2016).

17. "Kinezi izradili studiju za autoput Banjaluka - Mliništa" (2015).

18. "Autoput Banja Luka-Split je u interesu RS-a i FBiH" (2014).

\section{ABSTRACTS}

More than two decades after the Dayton peace agreement, Bosnia and Herzegovina is still stuck in an ethnically based struggle over territorial power. The former warring parties, and their economic and political elite, have succeeded in remaining in power during peacetime, and continue to influence the everyday life of the State, which is, to great extent organized along ethno-territorial lines of the institutional framework that was written in Dayton. In this paper we examined the system and logic of regional development as a consequence of this agreement, focusing on the development of transportation in the different ethno-territorial areas. We argue that because this field is delegated to the entities and thus to their ethnic elites, a large part of the development plans, policies and activities serve only the ethnic-based objectives of each entity, increasing the cohesion at their level instead of national cohesion. In this post conflict society, regional development is also used to control space and increase the territorial integration of the entities.

Plus de deux décennies après l'accord de paix de Dayton, la Bosnie-Herzégovine est toujours engluée dans une lutte pour le pouvoir territorial fondée sur l'ethnicité. Les anciens belligérants, ainsi que leurs élites économiques et politiques, ont réussi à se maintenir au pouvoir en temps de paix et continuent d'influencer la vie quotidienne de l'État, largement organisée selon les grandes lignes ethno-territoriales du cadre institutionnel élaboré à Dayton.

Dans cet article, nous examinons le fonctionnement du développement régional résultant de cet accord en nous focalisant sur le développement des transports dans les différentes zones ethnoterritoriales. Nous en concluons que, considérant que ce domaine est délégué aux entités et par conséquent à leurs élites ethniques, une part considérable des plans et des politiques de développement sert uniquement les objectifs basés sur l'ethnie dans chaque entité, ce qui accroît la cohésion à leur niveau plutôt qu'au niveau de l'État. Dans cette société post-conflit, le développement régional est également utilisé à des fins de contrôle de l'espace et d'intégration territoriale des différentes entités. 


\section{INDEX}

Keywords: regional development, transportation development, spatial planning, Bosnia and Herzegovina, ethnic policy, ethno-territorial logic

Mots-clés: développement régional, développement des transports, aménagement du territoire, Bosnie-Herzégovine, politique ethnique, logique ethno-territoriale

\section{AUTHORS}

\section{PÉTER REMÉNYI}

Department of Political Geography, Development and Regional Studies, University of Pécs (Hungary), remko@gamma.ttk.pte.hu

\section{ANDOR VÉGH}

Department of Political Geography, Development and Regional Studies, University of Pécs (Hungary), veghandor@gmail.com

\section{NORBERT PAP}

Department of Political Geography, Development and Regional Studies, University of Pécs (Hungary), pnorbert@gamma.ttk.pte.hu 